\title{
Government and Community Conflict Resolution in Gold Mining Areas without Permission of Bungo District, Jambi Province
}

\author{
Ane Rupaiedah ${ }^{1}$, Kismartini ${ }^{2}$ \\ Master of Public Administration Sciences \\ Faculty of Social and Political Science, Diponegoro University \\ Email: rupaiedah@gmail.com
}

(Received: March 21-2020; revised: April 20-2020; published: June 31-2020)

\begin{abstract}
Unlicensed Gold Mining in Bungo District caused prolonged conflict between the government and the community. This research is intended to analyze and describe the conflict resolution between the government and the community in the Unlicensed Gold Mining Area in Bungo District. In conducting research the Galtung Conflict Resolution theory is used with qualitative descriptive methods and Milles and Huberman data analysis techniques. The results showed that the process of resolving conflicts of gold mining without permission between the government and the community in Bungo District was carried out in several stages, namely: 1. Peacekeeping at this stage did not provide a deterrent effect for illegal gold miners, this is because during a joint operation of the TNI-POLRI and SatPOLPP occurred, gold miners have already escaped, 2. Peacemaking at this stage the Regional Government has coordinated with Rio or the village head together with the community to find solutions to the PETI problem. The solution offered by the community is the determination of a people's mining area (WPR), 3. Peacebuilding Bungo regency Regional Government through an integrated team to supervise the implementation of the PETI problem in its implementation is still constrained by social factors where the existence of changes in livelihoods that occur from generation to generation demanded on economic needs, and political factors in which there is a pattern of relations between law enforcement officials and cukong or people who facilitate gold mining without permission. To respond to the PETI problem in Bungo Regency: 1). The Bungo District Government needs to crack down on gold miners without permission, 2). Outreach will take place on the impacts of gold mining without permission, 3). Need to make a Regional Regulation (PERDA) in the management of community mining.
\end{abstract}

Keywords: Conflict; Conflict Resolution; Illegal Gold Mining (PETI).

\section{INTRODUCTION}

Indonesia is a nation that has abundant natural resources such as oil and gas, wood, arable land, and various other types of minerals. Improvement of community welfare occurs if the management is done wisely and fairly (Hernawan et al., 2017; Ismail et al., 2016; Razak \& Ali, 2020). Natural resources in Indonesia, for example gold. Gold in Indonesia ranks first in the largest gold mining in the world by looking at the results of gold production from the Grasberg Mine (Freeport) located in Papua Deil (2013). The wealth of gold resources in Indonesia is not only in Papua but on a small scale spread almost throughout the archipelago. 
298 Jurnal Ilmiah Ilmu Administrasi Publik: Jurnal Pemikiran dan Penelitian Administrasi Publik

Volume 1o Number 1, January - June 2020. Page 297-306

Unlicensed Gold Mining (PETI) has a definition that is a variety of mining which is carried out on the basis of the official mining law of the Kasworo Regional Government (2015). One form of PETI that develops in society is the gold mining material PETI. PETI gold extraction activities include the extraction process, mining ore processing, as well as amalgamation to obtain gold. Although the existence of PETI can increase the economic capacity of the community, the impact it has is also large. One of the things that can be found is the condition of PETI workers who do not have adequate training and safety, causing the rise of work accident cases that cause fatalities. In addition, PETI activities also cause environmental damage and pollution in the activity area and downstream areas of the location of PETI. Damage occurred in the land around mining activities that lost soil. While the gold processing waste (tailings) which is discharged into the river streams pollutes the surrounding environment.

This PETI is rife in Bungo District, Jambi Province which is marked by data from the Department of Energy and Mineral Resources of Jambi Province in 2018 as follows

Table. 1

Number of Gold Mining Without Permit Bungo District Year 2018

\begin{tabular}{|c|l|c|}
\hline Year & \multicolumn{1}{|c|}{ Sub-District } & Evidence \\
\hline 2017 & Babeko District (SepunggurVillage) & 24 Raft Dompeng \\
\hline 2018 & $\begin{array}{l}\text { District Rimbo tengah (Village Sungai Buluh), } \\
\text { District Tanah sepenggal (Village Teluk Pandak, } \\
\text { Village Empelu) }\end{array}$ & 65 Raft Dompeng \\
\hline
\end{tabular}

Source: Bungo Regional Police on Tribun Jambi page.com, 2018

The gold mining activities carried out by residents of Bungo Regency are fluctuating in nature, which is marked by a significant increase or decrease in erratic. Factors that influence the fluctuations in gold mining activities are social, political and economic conditions (Sheehy, 2014). Bungo District is now different from a few centuries before because it has become one of the places crowded with gold miners. Although in 1970-1999 the work of the residents was dominated by tapping rubber, palm oil, searching for forest products and farming, gold mining work continued on a scale and low intensity. Then gold mining activities increased again in 2000 followed by changes in gold mining patterns and techniques from the previous period. The existence of technological advances in mining gold is a factor causing these changes, namely the use of spray machines and suction machines known as dompeng. This gold mining activity has become one of the main jobs for the residents of Bungo District so this activity has been running for quite a long time. Usually people do gold mining in rivers, river bodies, or on land. Bungo community gold mining activities become difficult to stop because the community argued that the activity they carried out was based on economic factors as the main reason for the unstable price of rubber and palm oil. The difficulty of an inadequate source of income to support the family, makes them inevitably choose the way to mine for gold, even with the legal consequences they will face. Giving rise to friction of various views that resulted in open conflict between the joint apparatus of the TNI, Polri, and POL PP with the gold mining community without 
permission when raided.Referring to the definition of conflict Miall in (Awaru \& Syukur, 2019; Syukur \& Awaru, 2019) said that conflict is heterogeneous interests, values, and beliefs that are the result of changing social life. This is based on the conflict theory from Karl Marx which states that the emergence of conflict is one reaction of a particular functional system or series that fails in applying policies and regulations to a group. Illegal illegal gold mining in Bungo district is a social heritage that has been patterned up to the current generation is added to the economic problems and the absence of a product of regional regulations governing the management of gold mining which then becomes a source of conflict between the government and the community. Conflict resolution is an analysis that takes into consideration the needs of individuals and groups between them, namely the identity and recognition of institutions that change as meeting needs. (Awaru \& Syukur, 2019; Yang et al., 2013) defines conflict resolution as the ability to resolve differences and includes the main aspects of building social and morality for the skills and judgment of negotiating or compromising, and developing a sense of justice. Settlement must be sought in each conflict. Conflict between the two parties can usually be resolved directly by both. Sometimes it is also necessary to involve a third party as an intermediary and search for a solution as the Bungo District Government has worked in synergy with the TNI-POLRI apparatus in solving the problem of gold mining without ever becoming more widespread. According to (de Mattos Fagundes et al., 2016; Özdaşli, 2015; Peng \& Wu, 2019; Pichler et al., 2017) mentions the conflict resolution process includes 3 stages namely: 1 . Peacekeeping stopping or reducing violence (with military intervention that plays a role in maintaining the neutrality of peace), 2. Peacemaking The process of meeting and reconciling political attitudes and strategies between parties involved in conflict with mediation, negotiation, arbitration, especially at the level of elite leaders, 3. Peacebuilding The process of implementing reconstructions as well as social, political and economic changes to achieve lasting peace. Through the Peacebuilding ProcessObserving the above problems, the researchers conducted an analysis of Government and Community Conflict Resolution in the Bungo District of Jambi Province, using the John Galtung conflict resolution approach consisting of Peacekeeping, Peacemaking, Peacebulding.

\section{METHOD}

The method used in this research is descriptive qualitative with a literature approach. (Creswell \& Creswell, 2017) further said that "qualitative research is a research approach to uncovering certain social conditions by correctly describing reality, formed by words based on relevant data collection techniques obtained from natural situations. Data in this study were collected with study literature that studies various reference books, mass media, journals, and other scientific literature relating to the problem under study.Zed (2003) to analyze and illustrate Conflict Resolution between Government and People in the Bungo District Unlicensed Gold Mining Area. 
300|Jurnal Ilmiah Ilmu Administrasi Publik: Jurnal Pemikiran dan Penelitian Administrasi Publik Volume 10 Number 1, January - June 2020. Page 297-306

\section{RESULT AND DISCUSSION}

\section{Unlicensed Gold Mining Conflict in Bungo District}

According to (Mai-Bornu, 2019; Maurer, 2018; San-Akca et al., 2020), the term "conflict" has a literal meaning that is "fighting, war or struggle", is physical confrontation between several parties. Then the development of the definition occurs because of "sharp disagreement or opposition to various interests, ideas and others". So that conflict is defined as the perception of different interests (perceived divergence of interest), or a belief that the aspirations (desires, goals) of the conflicting parties cannot be achieved simultaneously (Çınar \& Kaban, 2012; Woodward et al., 2016; Yang et al., 2013). Conflict between the Bungo Regency government and the gold miners without permission takes place every time a joint TNI-POLRI operation is carried out in eradicating illegal gold miners operating in Bungo regency. The conflict continued continuously during the rampant illegal mining activities such as the burning of the raft of miners' rafters as quoted in the Jambione.com page written on Wednesday, November 21, 2018 until the conflict that occurred on May 10, 2020 where a conflict resulted in the stabbing and Hostage of members of the police while serving in control in the area of unlicensed gold mining in Bungo District, which was written on the Jambiekspres.co.id website on Monday, May 11, 2020. Illegal / unlicensed gold mining activities have flourished and it is difficult to break the chain of illegal mining. . One of the causes is related to the socio-economic and political aspects so that it becomes the root of the conflict problem.Associated with the socio-economic aspects of the illegal gold mining community / without permission, they try to maximize their power to obtain economically valuable livelihoods through the commodity gold which is one of the resources of the Bungo district and is related to the social aspects of the Bungo community who are active as traditional miners who become a legacy. Between the socio-economic processes are always related and can not be separated from the political aspects as Mansoben in Ramdhan et al (2014) states that politics means making, influencing, and implementing policies that concern the public interest of a society or groups or groups. the groups that are in it. Here we can see that there is a relationship between unlicensed gold miners and the political system in Bungo regency so that it is implemented the eradication of the problem of illegal gold mining is not finished even increasing every year.

\section{Process Conflict Resolution of Gold Mining Without Permits}

The conflict resolution process as (Galtung, 2015) approach consists of: 1). The Peacekeeping Model (security operation) model involves the security forces and the military to reduce conflicts and prevent the transmission of conflicts to other groups, 2). The Peacemaking Model is an effort between groups to negotiate with different interests. Some methods that can be applied in negotiations include: First, by force. Second, by law or conventional approaches. Legitimacy in government can lead to an effective legal approach. The authority and authority of a country in state management including reconciliation in 
conflict resolution will be lost without legitimacy, 3). The Peacebuilding Model is a strategy to restore destructive conditions caused by violence in conflict by bridging communication between the parties involved in the conflict. Five important things to consider at this stage include; First, interactions in this case are parties with equal status. Second, a supportive social environment. Third, intimate (not casual) communication. Kempat, the effect of communication that makes people happy and the fifth, there is a plan to achieve common goals.

\section{Peacekeeping}

Cessation or reduction of violence (through military interventions that maintain neutral peace). The efforts of the Bungo Regency Government have synergized with the TNI-POLRI apparatus in responding to the rampant problem of Unlicensed Gold Mining by confiscating and burning / destroying the fishing gear used for illegal gold mining. The following is a picture of a combustion of a single machine used for mining gold without permission.
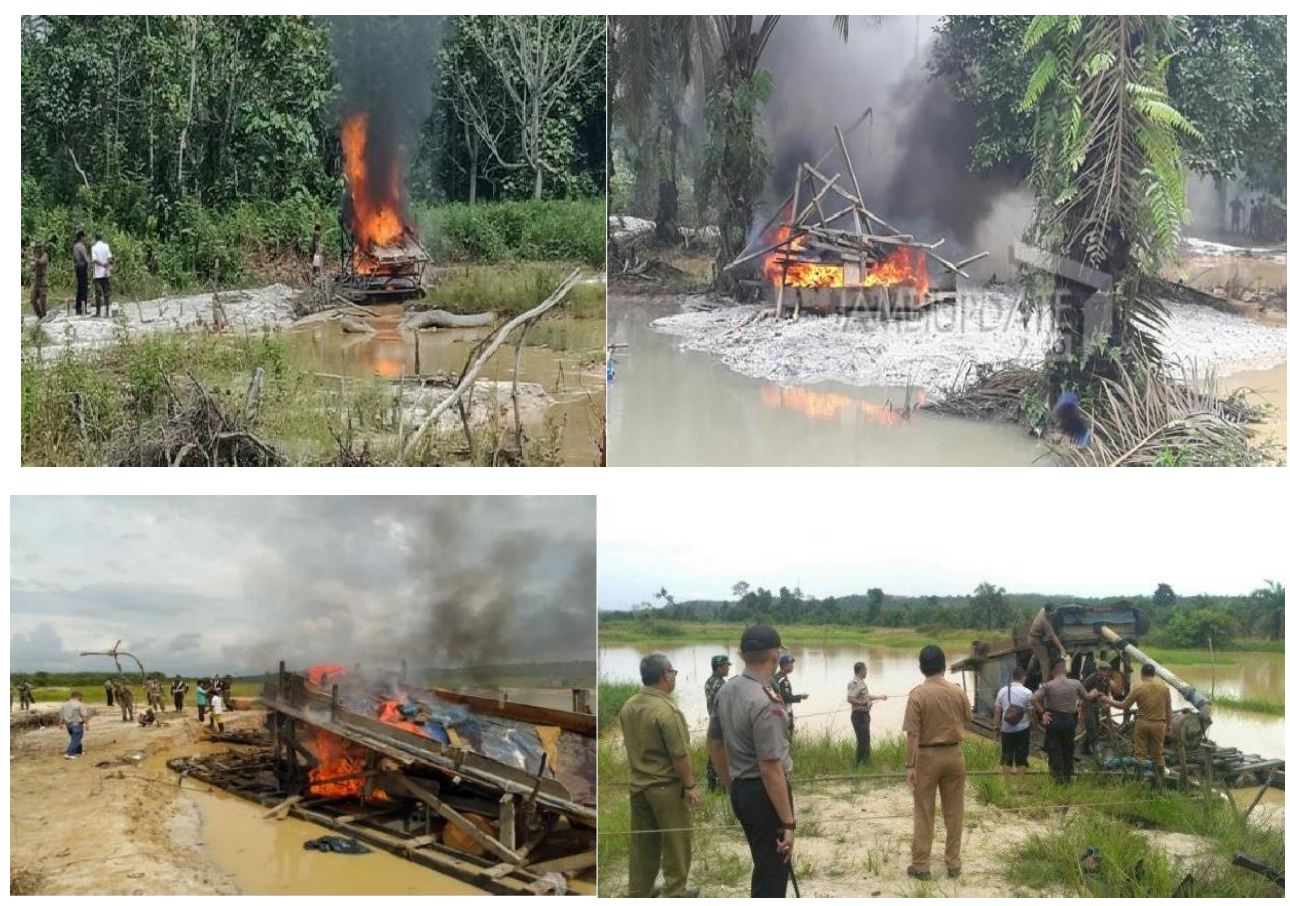

Source: Jambi-independent.com, 2019

Figure 1

Combustion / Destruction of equipment dompeng 
302 Jurnal Ilmiah Ilmu Administrasi Publik: Jurnal Pemikiran dan Penelitian Administrasi Publik

Volume 10 Number 1, January - June 2020. Page 297-306

The cooperation between the government and the TNI-POLRI apparatus does not create a deterrent effect for illegal gold miners, this is because during a joint operation the gold miners have fled so that there are no arrests of gold miners without the permission

\section{Peacemaking}

The Peacemaking process is a process of mediation, negotiation, arbitration, especially at the level of elite leaders who become the meeting and reconciliation of political attitudes and strategies between conflicting parties. The Regional Government in an effort to suppress the level of Unlicensed Gold Mining in Bungo District, has coordinated with the Rio or the village head to synergize with his staff in following up on the increasingly widespread PETI issue. One of the solutions obtained when coordinating with the village head or rio with the surrounding community was that to overcome this PETI problem, it should be determined a people's mining area (WPR). According to Article 2 Letter n of Law Number 11 of 1967 concerning the basic provisions of mining, community mining is mining of all classes of excavated A, B, C materials by surrounding communities on a small scale and cooperating using simple tools for personal use. In addition, the interests of community mining are in accordance with existing regulations, community mining becomes a problem solver for the relevant local and regional economic problems (Liang et al., 2020; Zhang et al., 2019). WPR is a special area for conventional miners to mine excavation in accordance with applicable government regulations so that people do not lose their livelihoods. However, this solution was hindered by the absence of a local regulation that regulates mining management activities in the community. As in Act Number 4 of 2009 concerning mineral and coal mining, Regency / City Regional Regulations require further provisions. As a requirement and legal basis for the local government which is authorized to manage the people of Sulaiman mining (2013).

\section{Peacebuilding}

The lasting peace can be achieved with the implementation of rebuilding or social, political and economic changes. In connection with (Peluso, 2018) which states the Prevention of the problem of Gold Mining Without Permits (PETI) always has to go through problems that create a dilemma. This dilemma is because PETI is associated with the lives of the poor without the ability to utilize economic resources due to limited education, expertise and skills. If the gold mining without permission is closed, it means adding unemployed people and poverty level, while allowing the operation is an act of violation of existing laws and regulations. Through the Peacebuilding Process. As in Inpres No 03 of 2000 which says that: A regional integrated team formed by the regional government coordinates the central integrated team with all relevant regional institutions in overcoming PETI, supervising and controlling efforts to increase the area to remain smooth and safe. However, the implementation in the field has not been running optimally, the Bungo District Government through an integrated team for supervision in the implementation of the PETI problem has not acted decisively because there are still many cukong or people who fund / facilitate gold mining without permission. As reported by Tribumjambi.com on Tuesday, July 12, 2016. 
Another factor that causes less than the maximum control of the issue of PETI is also due to social conditions where gold mining has traditionally been hereditary. (Li et al., 2016) in his research stated that people's orientation towards livelihoods influences changes in livelihoods themselves, which in general in Indonesia make their living in the agricultural sector. Changing livelihood orientation is defined by the changing mindset of society and influencing future actions, the beginning of the main work of the community in the agrarian field and then shifting to the non-agrarian field. The pattern of community thinking in this case according to Hegel affects the determination of community action. This shift in thought patterns has shown symptoms that occur significantly in the community of (Dickinson et al., 2020; Fredrick et al., 2020). so that with the thought of becoming a gold miner, it can overcome and meet the demands of economic needs that cause many people in Bungo regency to change professions to become illegal gold miners. Next there is a political factor where there is collaboration between unscrupulous people with the cukong so that gold mining without permission in Bungo Regency is increasingly rife. As (Halim et al., 2018) that the interests of political economy play an important role in the absence of permits to conduct gold mining activities, in the presence of illegal beneficiaries including residents of mining actors with capital holders, capital holders with law enforcement officials, and the government prohibits or issue a policy. Thus causing patterns of relations between individual law enforcement officers with unlicensed gold mining cukongs operating freely and in fact the government is letting it.

\section{CONCLUSION}

Based on the results of the analysis of the discussion it can be concluded that the process of Government and Community Conflict Resolution in the Gold Mining Area without a License in the Bungo District of Jambi Province. Not yet running optimally, this has been found to be a number of obstacles in the conflict resolution process including: 1) Peacekeeping at this stage the efforts of the Bungo district government have synergized with the TNI-POLRI apparatus in dealing with PETI issues, but these efforts did not have a red effect for illegal gold miners because the operation took place, the gold miners had fled so that there were no arrests of the gold miners without permission. 2) Peacemaking at this stage had been coordinated between the Bungo Regency government, with the rio or village heads to find solutions to the PETI problem. The solution obtained is that it needs to be determined a community mining area (WPR), but this solution is hindered by the absence of a local regulation governing community mining management in Bungo District, 3) Peobuilding of the Bungo Regency Government through an integrated team in reconstructing social, political, economic for the achievement of peace in its implementation has not been maximally caused by social and political factors. Social factors in the community where gold mining has traditionally been hereditary and demands for economic needs have caused many people to switch professions to become illegal gold miners, along with political factors where there is a pattern of relations between the law enforcement officials and the gold mining financiers without permission which causes unlicensed gold mining (PETI) flourished operating. 
304|Jurnal Ilmiah Ilmu Administrasi Publik: Jurnal Pemikiran dan Penelitian Administrasi Publik Volume 1o Number 1, January - June 2020. Page 297-306

\section{REFERENCES}

Awaru, A. O., \& Syukur, M. (2019). Dialectics of Student Conflict in Makassar State University. International Conference on Social Science 2019 (ICSS 2019).

Çınar, F., \& Kaban, A. (2012). Conflict Management and Visionary Leadership: An Application in Hospital Organizations. Procedia - Social and Behavioral Sciences, 58, 197-206. https://doi.org/https://doi.org/10.1016/j.sbspro.2012.09.993

Creswell, J. W., \& Creswell, J. D. (2017). Research design: Qualitative, quantitative, and mixed methods approaches. Sage publications.

de Mattos Fagundes, P., Padula, A. D., \& Padilha, A. C. M. (2016). Interdependent international relations and the expansion of ethanol production and consumption: the Brazilian perspective. Journal of Cleaner Production, 133, 616-630. https://doi.org/https://doi.org/10.1016/j.jclepro.2016.05.006

Dickinson, A., Daniel, M., Marin, A., Gaonkar, B., Dapretto, M., McDonald, N., \& Jeste, S. (2020). Multivariate neural connectivity patterns in early infancy predict later autism symptoms. Biological Psychiatry: Cognitive Neuroscience and Neuroimaging. https://doi.org/https://doi.org/10.1016/j.bpsc.2020.06.003

Fredrick, J. W., Kofler, M. J., Jarrett, M. A., Burns, G. L., Luebbe, A. M., Garner, A. A., Harmon, S. L., \& Becker, S. P. (2020). Sluggish cognitive tempo and ADHD symptoms in relation to task-unrelated thought: Examining unique links with mindwandering and rumination. Journal of Psychiatric Research, 123, 95-101. https://doi.org/https://doi.org/10.1016/j.jpsychires.2020.01.016

Galtung, J. (2015). Peace (J. D. B. T.-I. E. of the S. \& B. S. (Second E. Wright (ed.); pp. 618-623). Elsevier. https://doi.org/https://doi.org/10.1016/B978-0-08-097086-8.960197

Halim, R., Muhlin, M., \& Salam, R. (2018). Political participation of communities in the Legislative General Elections (Pemilu). Masyarakat, Kebudayaan Dan Politik, 31(3), 278-290.

Hernawan, H., Salam, R., Haerul, H., \& Suprianto, S. (2017). Regional Council Role in the Welfare Society Program.

Ismail, A., Sulur, A. H., Akib, H., \& Salam, R. (2016). Snapshot of Society Social-Economic Welfare based on Human Development Index in Polewali Mandar Regency, Indonesia. International Conference on Public Organization VI (ICONPO VI), 847-858.

Li, N., Toppinen, A., \& Lantta, M. (2016). Managerial Perceptions of SMEs in the Wood Industry Supply Chain on Corporate Responsibility and Competitive Advantage: Evidence from China and Finland. Journal of Small Business Management Editor, 54(1), 162-186. 
Liang, Y., Zhou, K., Li, X., Zhou, Z., Sun, W., \& Zeng, J. (2020). Effectiveness of highspeed railway on regional economic growth for less developed areas. Journal of Transport Geography, 82, https://doi.org/https://doi.org/10.1016/j.jtrangeo.2019.102621

Mai-Bornu, Z. (2019). Oil, conflict, and the dynamics of resource struggle in the Niger Delta: A comparison of the Ogoni and Ijaw movements. The Extractive Industries and Society, 6(4), 1282-1291. https://doi.org/https://doi.org/10.1016/j.exis.2019.10.002

Maurer, J. H. (2018). The Struggle for Sea Power: Lessons from the Great War. Orbis, 62(2), 184-203. https://doi.org/https://doi.org/10.1016/j.orbis.2018.02.001

Özdaşli, E. (2015). Key Trends, Issues and Solution Offers of International Relations Education in Turkey. Procedia - Social and Behavioral Sciences, 174, 2934-2939. https://doi.org/https://doi.org/10.1016/j.sbspro.2015.01.1031

Peluso, N. L. (2018). Entangled Territories in Small-Scale Gold Mining Frontiers: Labor Practices, Property, and Secrets in Indonesian Gold Country. World Development, 101, 400-416. https://doi.org/https://doi.org/10.1016/j.worlddev.2016.11.003

Peng, R.-Z., \& Wu, W.-P. (2019). Measuring communication patterns and intercultural transformation of international students in cross-cultural adaptation. International $\begin{array}{lllll}\text { Journal of Intercultural Relations, } & 70, & 78-88 .\end{array}$ https://doi.org/https://doi.org/10.1016/j.ijintrel.2019.03.004

Pichler, M., Schaffartzik, A., Haberl, H., \& Görg, C. (2017). Drivers of society-nature relations in the Anthropocene and their implications for sustainability transformations. Current Opinion in Environmental Sustainability, 26-27, 32-36. https://doi.org/https://doi.org/10.1016/j.cosust.2017.01.017

Razak, M. R. R., \& Ali, A. (2020). child social welfare institution participation in the implementation of good governance. Jurnal Ilmiah Ilmu Administrasi Publik, 9(2), 345-354.

San-Akca, B., Sever, S. D., \& Yilmaz, S. (2020). Does natural gas fuel civil war? Rethinking energy security, international relations, and fossil-fuel conflict. Energy Research \& Social Science, 70, 101690. https://doi.org/https://doi.org/10.1016/j.erss.2020.101690

Sheehy, B. (2014). Defining CSR: Problems and Solutions. Journal of Business Ethics, 131(3), 625-648. https://doi.org/10.1007/s10551-014-2281-x

Syukur, M., \& Awaru, O. (2019). Opportunities and Challenges of Organic Agriculture in the Era of Industrial Revolution 4.0 (A Case Study at Bulukumba Regency; South Sulawesi Province). International Conference on Social Science 2019 (ICSS 2019).

Woodward, A., Sondorp, E., Witter, S., \& Martineau, T. (2016). Health systems research in fragile and conflict-affected states: a research agenda-setting exercise. Health Research Policy and Systems, 14(1), 51. 
306|Jurnal Ilmiah Ilmu Administrasi Publik: Jurnal Pemikiran dan Penelitian Administrasi Publik Volume 1o Number 1, January - June 2020. Page 297-306

Yang, J., Ryan, C., \& Zhang, L. (2013). Social conflict in communities impacted by tourism. Tourism Management,
https://doi.org/https://doi.org/10.1016/j.tourman.2012.06.002

Zhang, J., Fu, X., \& Morris, H. (2019). Construction of indicator system of regional economic system impact factors based on fractional differential equations. Chaos, $\begin{array}{lllll}\text { Solitons } & \& & \text { Fractals, } & \text { 25-33. }\end{array}$ https://doi.org/https://doi.org/10.1016/j.chaos.2019.07.036 